\title{
Sound Levels And Spectra At Ikot Uduak (MCC) Timber Market, Calabar, Cross River State, Nigeria
}

\author{
Okoro, R.C. \\ Bassey D.E. \\ Umunnah, R.A. \\ Electronics and Computer Technology Unit, \\ Department of Physics, University of Calabar, Calabar
}

doi: 10.19044/esj.2016.v12n15p231 URL:http://dx.doi.org/10.19044/esj.2016.v12n15p231

\begin{abstract}
Acoustic and physical parameters of machines at Ikot Uduak timber market in Calabar, Cross River State, Nigeria were measured using a sound level meter and a real time frequency analyzer. The sound level meter was Mastech model MS6700. This has 30dB -130dB capability, with an accuracy of $\pm 1.5 \mathrm{~dB}$. Real Time Audio Spectrum Analyzer, version 3.3 was used. The results showed that A-weighted sound levels with the meter at $1 \mathrm{~m}$ away from the wood working machines were $100.5 \mathrm{dBA}, 98.5 \mathrm{dBA}, 98.2 \mathrm{dBA}, 101.5$ $\mathrm{dBA}$ and $90.5 \mathrm{dBA}$ for Band saw, Table saw, Plainer, Spindle/Curving machine and the Drilling machine respectively. From this, the threshold for dangerous levels of noise, as stipulated by the Academy of Pediatrics and the National Campaign for Hearing and Health, which is $85 \mathrm{~dB}$., and the Occupational Safety and Health Act (OSHA) permissible level of 90dBA for 8-hour day and 5 days a week, have been exceeded, and this could lead to hearing impairments.
\end{abstract}

Keywords: Timber market, Wood working machines, Acoustic parameters, Sound level meter, A-weighted sound levels, Audio spectrum analyzer, Hearing impairment.

\section{INTRODUCTION}

Sound is said to be disturbance which travels in form of an audible mechanical wave of pressure and displacement, through a medium such as air or water (WEC, 1969). Sound, occasionally, can be taken as vibrations with frequencies that are within the audio range of humans and some domestic animals (HMC, 2000). Such disturbances are produced by sound sources such as the vibrating diaphragm of a stereo speaker, barks from domestic animals and spoken communications with family and friends. 
Noise, on the other hand, is defined as unpredictable sound, especially loud ones, which upset people or make it hard for them to hear 'desired' sound (EPA, 2009). In industries generally, noise is one of the most undesired and unavoidable by-products of modern mechanical operations and a prolonged exposure to it of $85 \mathrm{~dB}$ (which is the threshold for dangerous levels of noise, based on the stipulations of the Academy of Pediatrics and the National Campaign for Hearing and Health) and above, can lead to hearing impairments, hypertension, ischemic heart diseases, annoyance, and sleep disturbance (Field, 1993).

Some Timber Market workers in Nigeria have been diagnosed with some of these noise related ailments. Some of these diseases, like high blood pressure can lead to a premature loss of life (Rosen et al, 1965). There is also a general low level of concentration on individuals living around timber markets. Therefore, there is need for this study to recommend possible ways of ameliorating these problems. The goals of the study are to:

i. Ascertain the sound levels produced by the woodworking machines in the Timber Market in Calabar

ii. Compare the results with the sound levels accepted for human and his environment

iii. $\quad$ Reduce the noise related health challenges in our society through proper advice and government regulations.

The machines available in the timber market were identified through a field survey. They are (with their machine code): Band saw (IUM1), Table saw (IUM2), Plainer (IUM3), Spindle/Curving machine (IUM4) and the Drilling machine (IUM5). The focus was only on the noise levels from the woodworking machines but not on other environmental issues such as noise from eateries, beer parlors, generating sets, and so on. The research took place between April and May 2015, and about fifty-five (55) woodworkers were interviewed.

\section{METHODOLOGY \\ I. Materials}

The following materials were used in carrying out this research work:

i. $\quad$ Digital Sound Level Meter, Mastech model MS6700. This model can measure sound between $30 \mathrm{~dB}-130 \mathrm{~dB}$ at accuracy of up to \pm $1.5 \mathrm{~dB}$. It has a frequency range of $31.5 \mathrm{~Hz}$ to $8.5 \mathrm{KHz}$.

ii. Real time audio spectrum analyzer, version 3.3. It is a collection of real-time instruments which are software-based and it is used for testing and examining audio systems making use of a PC with elementary sound input/output capability. 


\section{Methods}

The noise levels from the operation of each of the available wood working machine were measured at a place where the respondents reside and are regularly engaged in remunerative activities. Measurements were also made very close to the machine itself as it concerns the operators. The following procedures were strictly adhered to;

a. The weighting network of the sound level meter was put at the "A" position and the variability changes put at "slow" response.

b. The sound level meter was set to its best operation and maintained throughout the period of measurement.

c. Readings were taken with the microphone placed at a height between 1.2 and 1.5 meters above the floor and in a congested area, it was placed between 3.0 and 3.5 meters from any vertical surface which can reflect.

d. The part of the microphone that has the highest sensitivity was faced towards the noise source(s).

e. Any unwanted signals that could interfere with the result, such as wind and electrical interference, were carefully avoided.

f. For all the days' measurements of the noise were taken, a standard source of sound (with accuracy up to $\pm 5 \mathrm{~dB}$ ) was used both at the beginning and at the end of measurements. This was to ascertain the sensitivity of the sound level meter. (Umunnah et al, 2015).

\section{RESULTS AND DISCUSSION}

Tables 1, 2 and 3 show the results of the objective measurements of sound in the market. Table 1 shows the machines/the machines locations, the number of samples, background noise, average noise of the samples examined and the power source. It is evident from the table that all the machines examined are eternally powered, meaning that the noise measured are only those of the woodworking machines and there are no interferences from a stand-by alternating current generating source. The Band saw (IUM1) produced the highest average sound level of $98.0 \mathrm{dBA}$ having the level meter at $1 \mathrm{~m}$ away from the machine, when the machine is not loaded. Drilling machine (IUM5) produced the least average sound of $82.5 \mathrm{dBA}$ at the same distance. 0

The relationship between the working condition and the sound pressure level produced by the machines is shown on table 2 . When loaded, Spindle/Curving machine (IUM4) produced the highest average sound pressure level of $101.5 \mathrm{dBA}$ while Drilling machine (IUM5) produced the least average sound pressure level of $90.5 \mathrm{dBA}$.

Similarly, table 3 shows the comparison that existed between the sound pressure levels, the working condition of the machines and the 
distances of the meter away from the machines. The table shows that Band Saw produced the highest average sound level at the working condition, of 87.6 dBA with the level meter at a distance of $10 \mathrm{~m}$ away from the machine, while the Spindle/Curving machine produced the highest average sound level at working condition, of $55.6 \mathrm{dBA}$ when the meter is positioned $25 \mathrm{~m}$ away from the machine.

The frequency response of Real Time Analyzer used, at $1 \mathrm{~m}$ away from the machines, is shown on Figures 1 to 5 for Band saw, Table saw, Plainer, Spindle/Curving machine and Drilling machine respectively. The frequency response is reasonably flat, showing that their noise spectra are Gaussian.

TABLE 1

Machine parameters

\begin{tabular}{llllll}
\hline Machine code & $\begin{array}{l}\text { Total } \\
\text { number of } \\
\text { samples } \\
\text { surveyed }\end{array}$ & $\begin{array}{l}\text { Background } \\
\text { Noise level } \\
(\mathrm{dBA})\end{array}$ & $\begin{array}{l}\text { Noise range } \\
(\mathrm{dBA})\end{array}$ & $\begin{array}{l}\text { Average noise } \\
\text { level of } \\
\text { samples } \\
\text { measured (dBA) } \\
\text { th-weighted) }\end{array}$ & $\begin{array}{l}\text { Power } \\
\text { source }\end{array}$ \\
\hline IUM1 & 4 & 44.5 & $95-98.5$ & 98.0 & External \\
IUM2 & 5 & 43.0 & $84-88.0$ & 86.0 & External \\
IUM3 & 7 & 41.0 & $94-98.0$ & 96.0 & External \\
IUM4 & 4 & 43.5 & $93-97.5$ & 95.5 & External \\
IUM5 & 6 & 43.0 & $75-86.5$ & 82.5 & External \\
\hline
\end{tabular}

TABLE 2

Relationship between sound pressure level and the working condition of the machines

\begin{tabular}{lll}
\hline Machine code & $\begin{array}{l}\text { Average sound level when } \\
\text { there is no load (dBA) }\end{array}$ & $\begin{array}{l}\text { Average sound level when } \\
\text { loaded (dBA) }\end{array}$ \\
\hline IUM1 & 98.0 & 100.5 \\
IUM2 & 86.0 & 98.5 \\
IUM3 & 96.0 & 98.2 \\
IUM4 & 95.5 & 101.5 \\
IUM5 & 82.5 & 90.5 \\
\hline
\end{tabular}

TABLE 3

Relationship between sound pressure levels, the working condition and the distance of the meter away from the machines

\begin{tabular}{lllll}
\hline $\begin{array}{l}\text { Machine } \\
\text { Code }\end{array}$ & $\begin{array}{l}\text { Working } \\
\text { condition }\end{array}$ & $\begin{array}{l}\text { One meter }(1 \mathrm{~m}) \\
\text { away, }(\mathrm{dBA}) \\
\text { (Average } \\
\text { background } \\
\text { noise=43.0dBA) }\end{array}$ & $\begin{array}{l}\text { Ten meters }(10 \mathrm{~m}) \\
\text { away, (dBA) } \\
\text { (Average } \\
\text { background } \\
\text { noise=45.5dBA) }\end{array}$ & $\begin{array}{l}\text { Twenty-five meters } \\
(25 \mathrm{~m}) \text { away, (dBA) } \\
\text { (Average } \\
\text { background } \\
\text { noise=48.0dBA) }\end{array}$ \\
\hline IUM1 & No load & 98.0 & 84.5 & 51.5 \\
& Loaded & 100.5 & 87.6 & 54.7 \\
IUM2 & No load & 86.0 & 70.5 & 45.0 \\
& Loaded & 98.5 & 87.0 & 55.5 \\
IUM3 & No load & 96.0 & 80.5 & 49.0 \\
\hline
\end{tabular}




\begin{tabular}{lllll}
\hline & Loaded & 98.2 & 86.5 & 52.7 \\
IUM4 & No load & 95.5 & 80.5 & 49.5 \\
& Loaded & 101.5 & 87.5 & 55.6 \\
IUM5 & No load & 82.5 & 68.4 & 40.5 \\
& Loaded & 90.5 & 77.5 & 45.0 \\
\hline
\end{tabular}

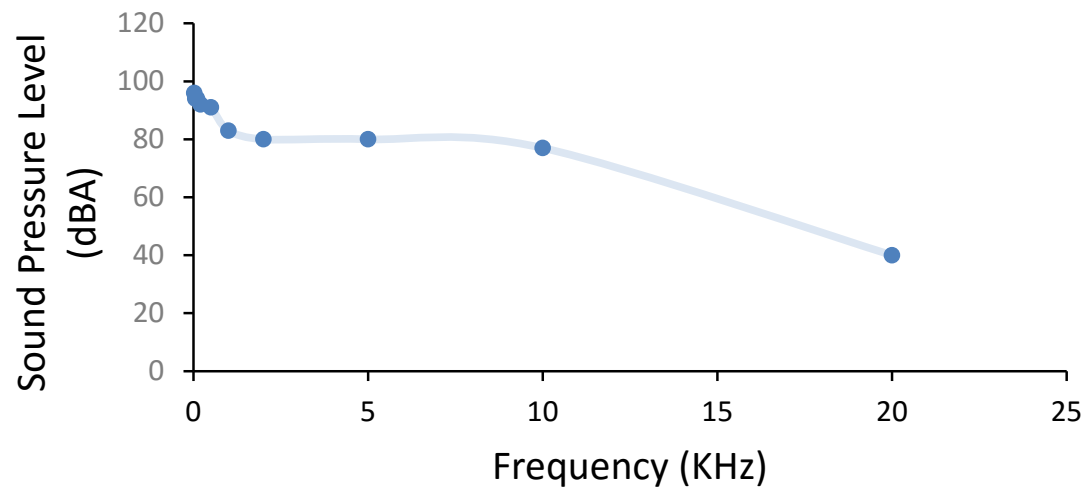

FIG. 1: Frequency analysis of noise from the band saw

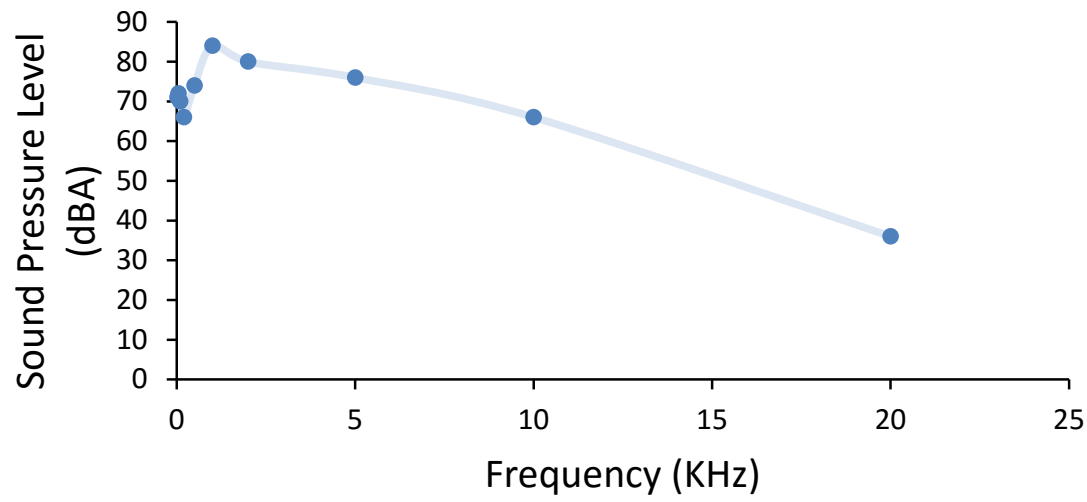

FIG. 2: Frequency analysis of noise from the table saw



FIG. 3: Frequency analysis of noise from the plainer 


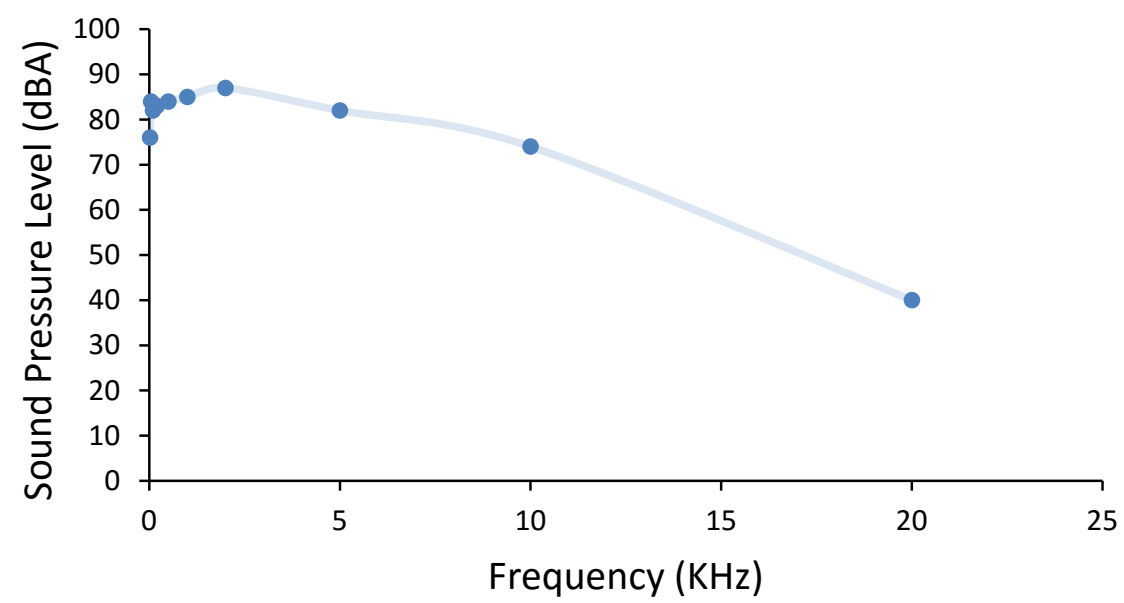

FIG. 4: Frequency analysis of noise from the spindle/curving machine

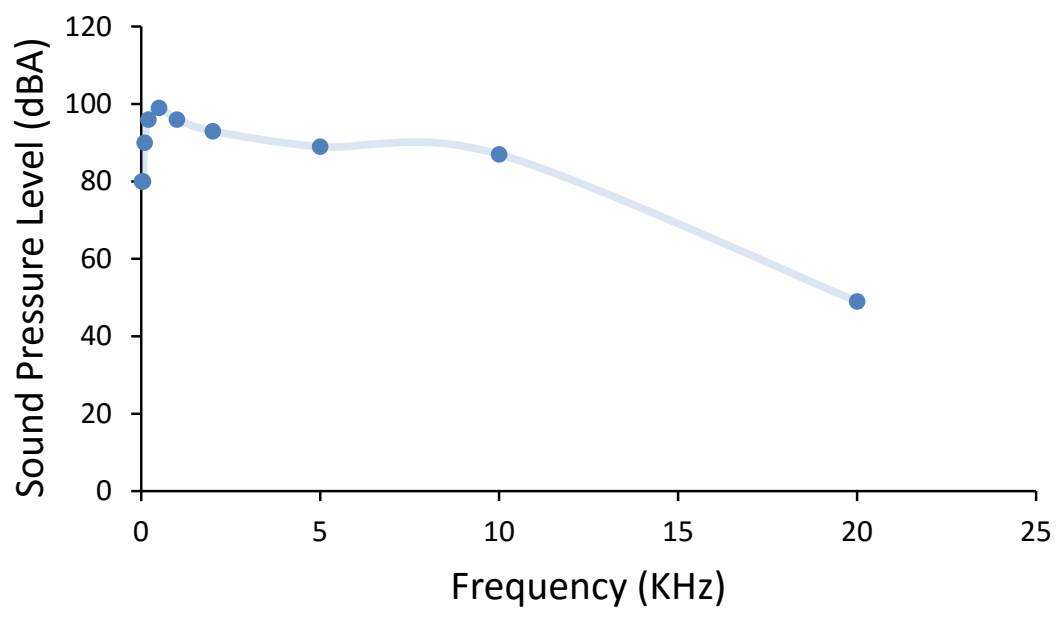

FIG.5: Frequency analysis of noise from the drilling machine

The distances of the sound level meter, chosen for measurement, that is $1 \mathrm{~m}, 10 \mathrm{~m}$ and $25 \mathrm{~m}$ away from the machines, were to have a reasonable radius which will accommodate the people working or doing businesses around the measurement locations. It can be seen that there is a gradual reduction in the noise levels as the distance between the meter and the noise source is increased. This is in accordance with the well-established inverse distance law which states that the level of sound pressure decreases in inverse proportion to the distance $1 / \mathrm{r}$ away from the source of the sound. All measurements made with the sound level meter at a distance of $10 \mathrm{~m}$ and above are all below $90 \mathrm{dBA}$, as shown on Figure 6 below. 


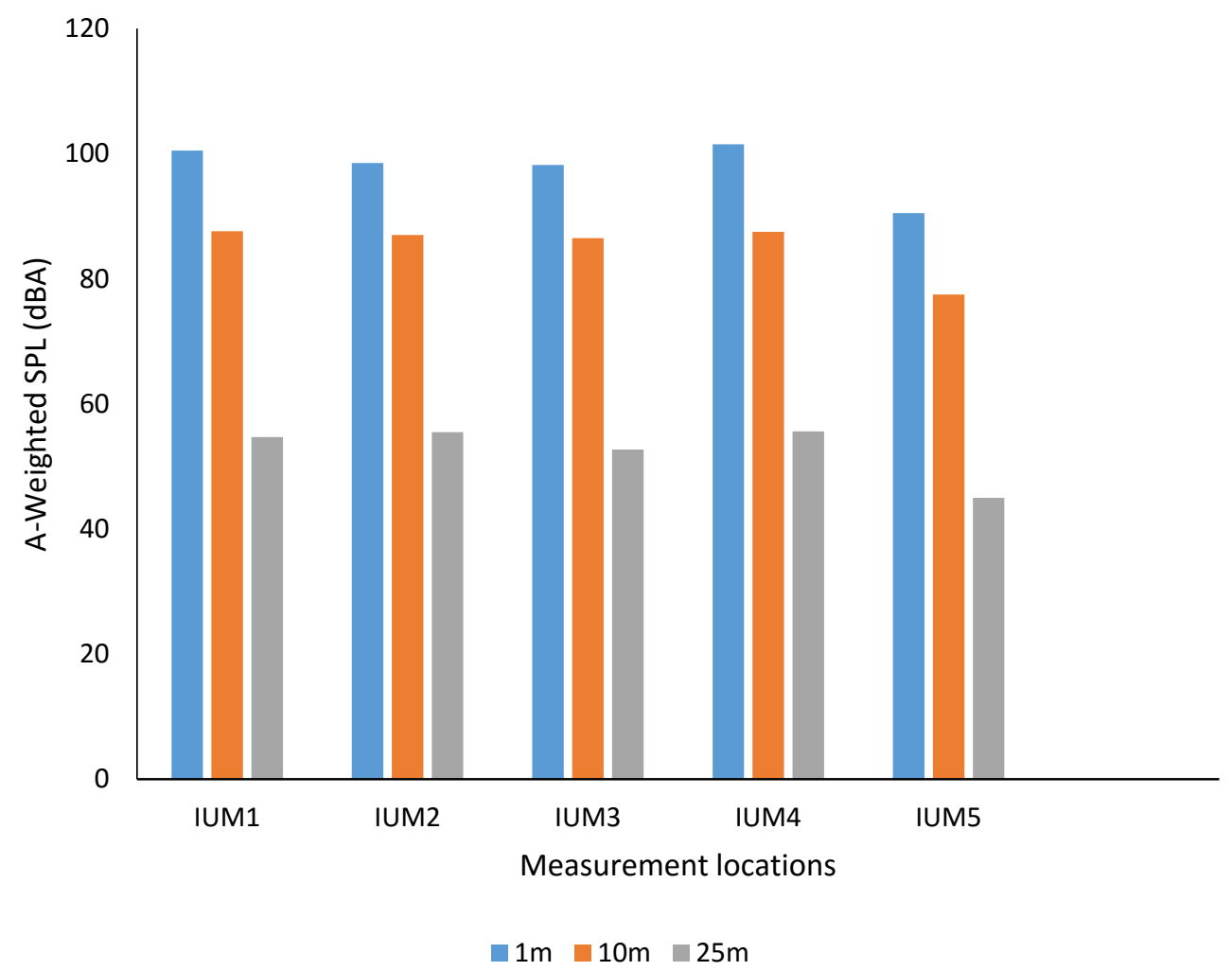

FIG. 6: Relationship between sound level and distance of the level meter away from the machines

\section{CONCLUSION}

The threshold for dangerous levels of noise, as stipulated by the Academy of Pediatrics and the National Campaign for Hearing and Health is $85 \mathrm{~dB}$. All the sounds levels measured at $10 \mathrm{~m}$ away from the machines are within this dangerous levels. At $25 \mathrm{~m}$ away from the machines, all sound levels measured were below $60 \mathrm{~dB}$. Hence, we establish that from this research work, the minimum distance that a business outlet or a shop should be established from a woodworking machine is $25 \mathrm{~m}$. This is in line with the work by Umunnah et al 2015. Also, the workers were observed to have violated the following recommendations for Hearing Protection by OSHA (OSHA Requirements 29 CFR 1910.95 Occupational Noise Exposure), which stipulates that:

i) Employees exposed to 8-hour TWA (Time-Weighted-Average) levels of noise of $85 \mathrm{~dB}$ or above should be provided with hearing protectors and these protectors must be worn by all employees exposed to a TWA of $90 \mathrm{~dB}(\mathrm{~A})$ and above.

ii) The employees must not be charged for these protectors. 
iii) Employees shall be made to willingly select suitable hearing protectors.

It can therefore be concluded that the workers within these conditions as stated above probably have hearing impairments and other noise related ailments.

\section{References:}

Akpan, E. R., Offem, J. O. \& Nya, A. E. (2006). Baseline ecological studies of the Great Kwa River, Nigeria I: Physio-chemical studies. Ecoserve. Retrieved 2011-09-08.

American Academy of Paediatrics, Committee on Environmental Health (1997). Noise: a hazard to the fetus and newborn. Pediatrics. 100:724-727.

Eja, E. I.; Inah, S. A.; Yaro, M. A. \& Inyang, I. O. (2011). The consequences of rapid population growth on housing in Calabar Metropolis. African Journal of Social Sciences, 1 (2): 84-94.

Field, J. M. (1993). Effect of personal and situational variables upon noise annoyance in residential areas. Journal of the Acoustical Society of America, 93: 2753-2763.

Gerges, S. N. Y. (1992). Ruído: Fundamentos e controle. Santa Catarina: Universidade Federal de Santa Catarina, 600.

Houghton Mifflin Company (HMC) (2000). The American Heritage Dictionary of the English Language (4th ed.). Archived from the original on June 25, 2008. Retrieved May 20, 2010.

International Electrotechnical Commission (IEC) (2003). International standard 61672-2:2003. Sound level meters - Part 2: Pattern evaluation tests.

Retrieved August 9, $\quad 2011$ from http://www.cirrusresearch.co.uk/blog/2012/07/ iec-61672-a-standard-forsound-level-meters-in-three-parts/

International Standards Organization (ISO) (2010). ISO 3746:2010. Acoustics -- Determination of sound power levels and sound energy levels of noise sources using sound pressure -- Survey method using an enveloping measurement surface over a reflecting plane. Retrieved August 21, 2011 from https://www.iso.org/obp/ui/\#iso:std:iso:3746:ed-3:v1:en

Mbian, A. B., (2009). Measurement and analysis of electricity generator plant noise and impact on residents in Calabar, Nigeria. Unpublished M.Sc. thesis, University of Calabar, Nigeria.

Molino, J. A. (1979). Annoyance and noise. In C. M. Harris (Ed.), Handbook of noise control ( $2^{\text {nd }}$ ed.). New York: McGraw-Hill.

Occupational Safety and Health Administration (OSHA) (1970). General industry standard. Table G-16, 29 CFR 1910.95.

Onuu, M. U. (2000). Noise levels and anti-noise laws. The Guardian. July 4, 16. 
Onuu, M. U. \& Menkiti, A. I. (1996). Analysis of Nigerian community response to road traffic noise. Journal of Science Engineering and Technology, 3: 536-547.

Optiz, H. (1968). A discussion on the origin and treatment of noise in industrial environment noise gears. Proceedings of the Royal Society, 12: 369-380.

Rosen, S. \& Olin, P. (1965). Hearing Loss and Coronary Heart Disease. Archives of Otolaryngology, 82:236.

Sehrndt, G. A., Parthey, W. \& Gerges, S. N. Y. (2006). Noise sources. Retrieved August 3, 2012 from http://www.who.int/occupational_health/publications/noise5.pdf Umunnah, R. A. \& Okon, B. E. (2015). A Survey of the Noise Generated by Timber Market Machines and Its Health Implications On the Workers and Their Environment, In Calabar, Cross River State. International Journal of Science and Engineering Research, 6 (5), 1713-1721.

United States Environmental Protection Agency (EPA) (2009). Noise Pollution. Revised Regulation for the Labeling of Hearing Protection Devices (HPD) Proposed. Retrieved 2013-09-24.

United States Environmental Protection Agency (EPA) (1978). Noise: A health problem. Washington DC: Office of Noise Abatement and Control, 22.

Western Electric Company (WEC) (1969). Fundamentals of Telephone Communication Systems. p. 2.1. 